Tingting Lu, Fangzhu Zhang, Fulong Wu. 2019. The variegated role of the state in different gated neighbourhoods in China. Urban Studies (accepted version).

\title{
The variegated role of the state in different gated neighbourhoods in China
}

\begin{abstract}
Housing commodification has led to the development of gated neighbourhoods in China. However, these gated neighbourhoods are very different, including 'commodity housing', affordable housing and resettlement housing. They might not be the same as the commonly known 'gated communities' which are characterised by both gating and private governance. Using three cases in the city of Wenzhou, we analyse the motivation of development, service provision and property management, and neighbourhood control. In commodity housing, the state is still visible and self-governance is limited, while the real estate developer has led land development and property management. In affordable housing, the state regulates standards and the prices of services, while the developer is the provider of these services. In resettlement housing, the state uses a state-owned enterprise to relocate households, while homeowners' associations and service charges are ineffective. All these cases demonstrate the important and variegated roles of the state and provide a more nuanced understanding of these gated neighbourhoods.
\end{abstract}

\section{Introduction}

In the Anglo-American context, gated communities are fortified urban settlements under private governance (Gordon, 2004; Le Goix and Webster, 2008). Their development is driven by the private interest to reorganise and redistribute public goods. The emergence of gated communities has provoked research debates on social segregation as a main implication (Pow, 2014). However, Kirby (2006) suggests paying more attention to these enclosed residential developments as they are contextualised in local society and politics. Furthermore, Fauveaud (2016) reinforces 
this point of view in a recent study, considering gated communities to have a diversity of developments and heterogeneous meanings. First, the variation in land rights, local development strategies and the power of territorial institutions; second, the diverse development contents, such as functions and locations; third, consumers' choices on housing and public goods; and finally, the interplay of different stakeholders during the production and governance of the enclosed space (ibid).

In China, new housing development at the scale of xiaoqu (community) has predominantly taken a gated form. Initially, this was because of housing privatisation. Since the termination of work-unit housing provision in 1998, housing has no longer been a form of welfare provided by the socialist state but has become a crucial category of consumption goods. In the 1990s, housing booms were sustained by massive capital investments (Wang and Murie, 2000; Zhou and Logan, 2008). Real estate developers have been required by national community design codes to build safe and aesthetic residential environments with physical boundaries. This government policy initially started the development of gated estates as a safer type of residence.

Apart from market development in the post-reform era, the production of residential enclaves in China is attributed to economic decentralisation and changing urban governance. The state has retained land ownership and planning power, but has involved market instruments for accelerating economic growth. However, local governments have undertaken the regulatory role in the suburbanisation processes where new residential development is concentrated (Shen and Wu, 2017). Meanwhile, market forces have begun to create impacts on neighbourhood governance, as for instance the establishment of homeowners' associations (HOAs) being required for new residential development. These organisations protect residents' property rights against developers, as well as hiring and dismissing professional property management companies which provide services for residents in the enclosed community. Consequently, new residential development has begun to display novel features, distinct from traditional residential forms such as courtyard housing and work-unit housing (He, 2013; Huang, 2006; Wu, 2005). 
There have been attempts to consider gated communities in urban China as market provision for the middle class (Breitung, 2012; Pow, 2009; Wissink et al., 2012). However, inadequate attention has been paid to different types of enclosed housing and their dynamics. In fact, the production and governance of newer residential space have been complicated by on-going processes of growth-driven suburbanisation and state-dominated urban redevelopment, which highlight the state's role (Wu, 2016). Instead of defining gated communities as private neighbourhoods or sites of neoliberalism, this paper examines all kinds of neighbourhood enclosure and gated residential neighbourhoods. Our main research question is the following: "Does the state play a role in these gated neighbourhoods?" Related to this main question, we also ask, "What are the initial motivations for the state to encourage these gated developments? What is the state's role in them? How are services, for example property management, provided? To what extent does the neighbourhood have self-governance?" By filling the knowledge gap regarding the nature of gated neighbourhoods in China and their governance, this paper endeavours to engage with wider conversations on gated communities under private governance.

\section{Explanations of gated communities: residential preference and local governance}

In the US, gated communities are seen as walled private neighbourhoods (Blakely and Snyder, 1997). Although gated communities are regarded as private neighbourhoods, they are produced due to different reasons and local conditions. Many studies have regarded gated communities as vehicles of urban neoliberalism (Pow, 2011) and spaces of social exclusion (Low, 2003) in correspondence with the production of urban space. Specifically, in countries that have less excessive inequality, market forces drive the development of gated communities for speculative suburban growth in Australia (Dowling et al., 2010); for global elites' consumption in Singapore (Pow, 2011); and for marking the differentiation of lifestyles in Canada (Rosen and Grant, 2011). Moreover, the emergence of gated communities is more a response to conflicting socio-political conditions than a result of neoliberal social and spatial transformations. Gated communities are produced to prevent urban crime and violence in Latin American cities (Coy and Pöhler, 2002), and to avoid ethnic and political conflicts, as studies from Malaysia (Tedong et al., 2015), South Africa 
(Morange et al., 2012) and Israel (Rosen and Razin, 2009) indicate. Additionally, the burgeoning literature based on Asian countries has tended to see the development of contemporary gated communities as a way of modernising urban space, as, for instance, in Vietnam it is part of urban mega project development (Labbé and Boudreau, 2015). In the Philippines, gated developments are associated with newer urban areas (Ortega, 2012), and in Cambodia, enclosed residential estates reflect symbolic and material urban development produced by new power relations between developers and local authorities (Fauveaud, 2016).

Regarding gated communities, there are two related views: residential preferences and local governance. First, North American literature tends to focus on residents' demand for private governance and the private sector's supply (Kirby, 2008; Walks, 2008). The underlying mechanisms are explained through Buchanan's (1965) public choice theory. Webster (2002) identifies a theoretical perspective to consider gated communities as club realms, where homeowners form economic or legal consumption rights over goods and services in a fee payment scheme. Gated communities therefore supply members with optimally scaled club goods and avoid free-riders, because the club mechanism concentrates on supply efficiency. Cséfalvay (2011) emphasises that residents have a strong impetus to choose gated communities when local governments fail to deploy vital governmental instruments. In a sense, gated communities are the exit option (Hirschman, 1970) for residents to choose when they are dissatisfied with local government. In France, residents of peri-urban communes support the clubbisation of municipal government, because they demand club-like management of residential environments (Charmes, 2009). However, for the explanation of residential preference, scholars challenge the club explanation of gated communities for overestimating residents' power and overlooking the state's role, because residents may buy into the community without having a rational economic choice, or may have little choice (Atkinson and Blandy, 2005; Glasze et al., 2005).

The second strand of literature uses the perspective of local governance. It focuses on the transformation of urban governance, particularly on how local government reduced the allocation of public resources (Imrie and Raco, 1999; Roitman et al., 2010). Gated communities are seen as a new form of urban governance which emerges from decentralisation and privatisation. They represent the 
transformation of urban governance into support of private governance, by which homeowners can make their own rules of governance. From this point of view, private governance is encouraged by local governments for piloting a way through urban changes, representing an evolution of collective cost arrangements (Foldvary, 1994). Nevertheless, concerning changing local governance, Fauveaud (2016) points out that gated communities are produced by specific social and political drives, and proposes a closer look at the process that shapes gated community development.

Gated neighbourhoods may be produced for a variety of reasons. Some may be due to residential preference, while others may be caused by political economic changes such as privatisation. Gating may not be purely produced by the change towards private governance. Policies affecting the supply side may create gated neighbourhoods for concrete and particular motivations. This study tries to make a novel contribution because it does not adhere to the assumption of private governance but rather critically interrogates the role of the state in making gated neighbourhoods. We demonstrate concrete and contextually-dependent motivations to build gated neighbourhoods. Our study also links the particular 'gated community' research with a more general understanding of 'neighbourhood governance'. In respect of Chinese neighbourhood governance, the role of the state is very important. In China, we see the production of residential enclosure with absent private governance and persistent state intervention.

\section{'Gated communities' in China}

This article uses a more general definition of gated communities. We include all gated forms of residential neighbourhoods developed since housing reform in China. Therefore, we exclude open-access or informal communities such as urban villages from our scope of study, even though in terms of governance these open-access communities might be governed by communities themselves (such as village collectives). These informal villages are very different from modern master-planned gated communities and do not have residential enclosure.

This open definition to include all forms of gated residential development is more appropriate because we do not assume these gated neighbourhoods are organised 
purely by private governance. Instead, we will examine their governance features and the process of development and service delivery, which allow us to see the role of the state in these gated neighbourhoods.

Studies on gated forms of residence have already indicated that there might be diverse types of gated communities. Enclosed residential developments involve multiple factors other than residential preference or changing governance, for example the fragmentation between different forms of land ownership or income differentiation. Webster et al. (2006) explain that Chinese new residential forms including gated communities, public housing estates and rural collectively owned settlements - present some characteristics of gated communities because of their different types of land ownership and governance. Based on the approach of housing provision, Breitung (2012) categorises Chinese residential enclaves into four types, namely commodity housing, work-unit housing areas, urban villages and staff dormitories. Zhang (2010) and He (2013) further stress that increasing income disparities have led to a stratified residential regime in urban China. Consequently, Chinese residential development takes a variegated form of 'enclave urbanism', which is characterised by spatial patchworks (Douglass et al., 2012; Wissink et al., 2012).

The majority of new Chinese residential development is now gated (Miao 2003), in contrast to North America where a majority of residential neighbourhoods are open to the public with only a small though increasing proportion of residential development in gated form. China has also had a long tradition of enclosed residential development ( $\mathrm{Wu}, 2005)$. For example, danwei, the basic unit of production, used to play a significant role in the development of exclusive living quarters for staff before the turn of this century (Bray, 2005; Huang, 2006). In this study, we focus on new residential areas built since the 1980s when the market mechanism of development was first introduced.

The first strand of literature emphasises changes in urban governance rather than residential preferences in the Chinese context (Huang, 2006; Webster et al., 2006; Wu, 2005). For example, Huang (2006) argues that gated communities represent a new form of political control, which helps communities to strengthen social solidarity in 
the post-reform era instead of promoting individualism. Zhang (2010, p. 210) suggests that it is not about a "transition from authoritarian control to individual freedom, but about how real estate privatisation has produced a different form of urban governance”. In enclosed residential areas, residents find it easier to set up HOAs and recruit property management companies to maintain their properties (He, 2015). Governance through HOAs encourages residents to address their own problems in gated community domains (Xu, 2008). The literature of governance reveals the need to examine development strategies, property management, and neighbourhood control. This strand of literature does not provide a conclusive and definitive answer regarding the role of the state. On the one hand, the changing method of governance (Wu, 2005; Zhang, 2010) and the emergent function of HOAs (He, 2015; Hendrikx and Wissink, 2017) are noted. On the other, private housing and the gated form do not reduce top-down collective control and state intervention (Huang, 2006; Zhang, 2010).

The second strand of literature on gated communities in China considers them as aesthetic spaces for residents who have a particular preference for their living environment. This type of explanation is similar to residential preference in the Western literature. Pow (2009) considers that the development of gated communities in Shanghai represents the preference of the middle class for greater residential privacy and for being away from state hegemony. $\mathrm{Wu}(2010)$ suggests that gated communities provide a means to package services for their residents. He (2013) describes gated communities as an emerging form of middle-class consumption for proclaiming class identity. Hendrikx and Wissink (2017) examine service provision in commodity housing estates and define gated communities as consumer clubs, following the economic explanations that emphasise the efficiency of 'club goods' over public service provision (Webster, 2002). These studies show that concern for security, or 'fear of crime' (Low, 2003), is not the main reason for enclosed Chinese residential development (Breitung, 2012). Instead, they believe the gated form is more attributable to the preference for residential quality. Regarding the role of the state, this strand of literature seems to suggest that there are more consumer choices and that moving into gated communities is at least initiated by households themselves or is due to particular preference. The role of the state is not explicitly discussed in the 
literature of residential preference for gated communities. An implicit assumption is that because of residential preference for privacy, the role of the state in the gated communities is weakened.

Although residential preference and governance change are not mutually exclusive explanations, they both suggest the rising role of market development and provision. The impact of market provision on neighbourhood governance is not entirely known, in particular with the reference to the role of the state.

\section{A case study of Wenzhou}

Wenzhou, a second-tier city located on the southeast coast of Zhejiang Province in the Yangtze River Delta region, has been playing a pioneering role in the market economy. It was one of the cities that pioneered the implementation of land marketisation and housing privatisation in post-reform China. The booming of private enterprises contributed more than $80 \%$ of local GDP and facilitated an active private economy. From the 1980 s to the 2010 s, Wenzhou's urbanisation rate leapt from $16 \%$ to $66 \%$, with a total of nine million registered residents hosted in the city (Wenzhou Statistic Bureau, 2010). The city has witnessed massive socio-spatial transformations. One of the crucial facts is the wide application of the gated form in new residential development.

There are significant institutional changes related to housing development and governance. At the city level, the municipality's planning strategies rely on the strong capabilities of local private capital for financing public goods provision. At the community level, the provision of infrastructural facilities and services in new residential development has been privatised to reduce public administration costs. Meanwhile, HOAs are established to supervise the market provision of services according to community governance regulations. With these policies, new residential development has been generically enclosed and privately managed like a gated community.

The proliferation of gated residential development should also be placed in the socio-political context of Wenzhou. Historically, Wenzhou was lacking in the volume 
of state-owned industries or farmlands, and thus residents preferred to run private businesses. From 1979 onwards, the adoption of a more market-oriented political economic regime provided greater opportunities for the local private sector.

Nevertheless, the Asian financial crisis in 1997 reduced export trading, driving local private capital to shift from manufacturing to the real estate industry. Particularly after the deepening of housing privatisation, the leasing of residential land became a main approach of the local government for gaining local revenues. This had significant social implications, one of which was widened housing disparities between locals and migrants. Members of the local middle class who had made a sufficient fortune from the development of private businesses began to long for new housing from the market, while migrants clustered in company dormitories provided by the owners of private enterprises or rented cheap accommodation in urban villages. In the most recent decade, the residential landscape has changed into an overwhelmingly gated style of community, as gated residential development became a cash pool for the local government, for developers from both the public and the private sectors, and for speculative homebuyers. Up to 2010 , over $43 \%$ of households lived in gated residential developments (Wenzhou Statistics Bureau, 2010).

For this paper 559 gated residential developments in Wenzhou were identified. Among them, Tongren, Luodong and European Town were chosen as three cases that represent different types of gated communities (Figure 1). Five field visits were made during 2013-2017. Thirty in-depth interviews with local officers, developers, residents, representatives of HOAs and managers of property management companies for the three cases were carried out from March 2013 to June 2017.

(Insert Figure 1 here)

\section{Tongren Garden: market-led gated residential development}

Tongren represents a case of market-led gated residential development. The site is located in an eastern suburb that has close access to the international airport. In this peripheral area, which used to be shabby and chaotic, there remained eight underdeveloped urban villages. Due to the low prices and the availability of suburban land, a state-owned real estate company, Shengzhi Tongren Group Co. Ltd (STGC), 
planned a development there. The development of Tongren emphasised the maximisation of market profits.

Privatisation for overcoming infrastructure constraints. The site used to be an unpopular residential choice for two main reasons: the lack of public infrastructure provision and the fact that the suburban lifestyle was neither a prevailing pursuit nor a rooted tradition. The municipality adopted market methods, shifting its financial burden of developing the suburban area to the private sector. Against this background, STGC called for marketing proposals from international design companies. The concept of the gated community was adopted as a strategy to overcome the shortage of public provision and the fragmentation of governance. Nevertheless, the development was reduced to focus on suburban landscapes and facilities due to infrastructural constraints. This was because public facilities were rarely provided in these peripheral urban villages. The developer believed that to "invest in infrastructure is a shortcut to a high rate of market return in a suburban project" (Developer, interviewed on 13/01/2014). STGC thus packaged Tongren with a clubhouse, a nursery, swimming pools and small yacht marinas within the physical enclosure. Costly infrastructure works (e.g. artificial islands), as well as low-density and suburban landscapes, were carefully designed and carried out.

By the same logic, STGC spent over 192 million Yuan on upgrading infrastructure in the surrounding area. The market development was a way of solving infrastructural shortages. The ultimate purpose was to increase property prices in the housing market.

The interaction between the developer and the municipality. Due to the lack of residential land and the high cost of brownfield renewal in the city centre, the municipal government made a decision to expand residential development towards the suburbs. The fundamental drive was the municipal government's intension to raise local revenues through suburban land development. During the suburbanisation process, five high-end residential zones were set up by the municipality, who sought domestic capital investments by trading off the development rights of land and housing. Tongren was a flagship project in one of these planned residential zones. The municipal government expropriated the collective land from existing urban villages, 
whose villagers were then relocated at a low cost by taking advantage of the underdeveloped periphery, and leased the land to STGC at a higher price via market bidding. Through this approach, public expenditures on land development were minimised, while the land-leasing fees and deed taxes contributed 286 million Yuan to local revenues for the local government.

STGC, as a patron for suburbanisation, also played an important role. Being a provincial-level state-owned enterprise (SOE), it was capable of negotiating with the municipality for access to various resources. The developer stressed the bureaucratic hierarchy when explaining its relationship with the local government. As the CEO explained:

"The general planning control on residential development is strict in China, except for those located in the remote area. Our project is comparatively more imaginable, as I succeed to negotiate with the planning authority for allowing a higher floor ratio and more villas. We want to maximise profits by creating a high-end and low-density community. Tongren is eventually built to have a 1.6 floor area ratio and a 54 per cent green space ratio, achieving the highest price in Wenzhou housing market" (Developer, interviewed on 28/02/2014).

With this relation, the municipality provided policy flexibility for the market-led development. In addition, the municipality helped to reduce the financial burden for STGC by dividing the land-leasing fees into four instalments and allowing multiple land mortgage loans. Place marketing strategies also went through smoothly with sufficient financial resources. By 2004, Tongren was completely constructed and sold to market property buyers. There was no doubt that the development of Tongren profited STGC and contributed vast revenues for the municipality. It consequently helped to attract more investments to new residential developments, resulting in the surging of land prices in the suburban area. The blurred relationship between developers and the municipality resulted in flexibility regarding the planning and financing of land development. It was a salient impetus for the local government to promote suburbanisation and extract revenues. 
The rising importance of property management. New residential development in the periphery was concerning as an area of power vacuum, owing to fragmented suburban governance. For suburban residential developments, the municipality intended to extend governance power via the approach of land-leasing, while reducing public expenses. With this purpose, the municipal government made a deal with STGC, requiring STGC to lead the development and to have an auxiliary property management company to provide services in the community. The municipal government supported this approach and thereafter was able to withdraw from the responsibilities of serving the neighbourhood and the surrounding suburban area.

The provision of services thus became another method of profit maximisation. Specifically, professional management companies took charge of providing a range of services and entertainment activities in the community. Homeowners were required to pay high monthly maintenance fees to these management companies. This led to the rising importance of property management (Zhang, 2010). In Tongren, the developer nominated a high-end private management company from the market, consisting of as many as 85 professional managers, technicians, security guards, and janitors. They carefully attended to community daily management, environment retrofitting and events arrangement. For instance, communal areas were swept daily and household garbage was collected twice a day. The private company considered the principle of community management as arranging efficient and customised services for households that required assistance, such as providing private butlers. As one manager explains:

"We host many social activities for the community and pay for all expenses. We have established good relations with homeowners by providing high-quality and customised services. For example, we organise special receptions for homeowners' weddings in the community. On many Chinese traditional holidays, we arrange banquets and parties for the entire community. It feels like a hometown village that everyone is attached to" (Member of property management company, interviewed on 16/03/2013).

The form of the gated community became a necessity, because it helped to define the development rights of land, and more importantly to ensure the use rights of 
privately provided services. The manager considered electronic gating systems, such as the Bluetooth recognition system and the electronic ID card system, as "advanced parts of community management, keeping services exclusive to registered vehicles and residents" (Manager, interviewed on 17/03/2013). These exclusive high-end services in Tongren helped to increase property prices in the market. On average, a detached house was sold for 30 million Yuan. The majority of residents were affluent locals, particularly entrepreneurs and the owners of private businesses, who favour professional management services for their properties.

The lack of self-governance. In Wenzhou, HOAs were formed in the mid-1990s. It was not until 2003, through issuing the Regulations on Property Management, that central government acknowledged the role of the HOA as a community organisation in new residential development. However, these policy regulations turned governance towards emphasising service provision rather than homeowners' empowerment.

In a market-led development, an HOA was established to assist in the provision of services. However, the Residents' Committee and Street Office largely influenced the work of the HOA by controlling the election of HOA board members as well as by monitoring the HOA's collective decisions and actions through the approach of political examination (zheng shen). Under these circumstances, the HOA's main responsibility was to hire and dismiss property management companies. As a board member of the HOA commented, "It is to purchase good services from the market rather than to manage the community by ourselves" (Member of HOA, interviewed on $21 / 05 / 2017$ ). In 2017 , some homeowners were dissatisfied with the poor quality of HOA's supervision of community management and appealed to community members to re-elect the board. Nevertheless, the re-election for self-governance failed, even though more than 113 homeowners participated in the vote, because the Residents' Committee turned down the validity of this joint-signed appeal.

The HOA does not have real power. A voter in Tongren said, "[the] HOA does not have power to protect our interest" (Resident, interviewed on 10/06/2017). However, while homeowners wish to have good services, they do not explicitly demand self-governance. A few residents, who were busy businessmen, considered the HOA impractical for community management. A resident who observed the entire 
process commented, "I would rather choose a property management company to solve immediate problems" (Resident, interviewed on 10/06/2017).

Later, regulations on the governance of new residential development were restored limiting the HOA to the role of property management. In this market-led gated community, the governance focused only on managing residents' consumption and services provided through property management. This is significantly different from self-governance that focuses on the political right of homeowners to decide community governance issues and influence tax regulations and public service provisions at the local level (McKenzie, 1998).

\section{Luodong: mixed state and market development}

Luodong was a case of mixed development with the intensive involvement of both the state and the market. The community was gated with a mix of commodity housing and affordable housing. Despite having private provision of $8,000 \mathrm{~m}^{2}$ community clubs and facilities, the development of Luodong differed from private governance due to strong state intervention.

State-regulated standards. The state initiated the housing commodification process, promoting new residential development with a variety of housing choices. In the early stages, the central government issued development guidance for housing experimentation at the local level. A national xiaokang (moderately prosperous) communities scheme played an instructional role for the market. The scheme stressed that housing developers should provide a socially mixed and hygienic environment in the community. It specifically referred to gatedness as an approach of community development.

Later, the state strengthened the development of affordable housing through a series of policies. These policies required that the housing market should supply commodity housing to high-income buyers and affordable housing to middle-income and low-income buyers. Political pressure was put on local governments to take responsibility for planning affordable housing. 
The Wenzhou municipal government assigned affordable housing development targets to different districts. The Ouhai district government intervened in the development of Luodong by using the mixed state and market approach, so was able to fulfil the municipal government's requirements and seek investment from the market. Therefore, the planning and governance of Luodong, unlike gated communities in American experiences where homeowners have the power to determine community design and residents' actions, were standardised by the state's regulatory power.

Profit-controlled development. The district government attempted to reduce public expenditure on mixed development by two means: controlling land-leasing and supervising the developer. It acquired 20 acres of collectively owned land, and removed 339 villagers who used to live and run small family businesses on the site. Compensation for relocation was considerably high. The district government shifted the responsibility for paying compensation to the developer by making it one of the land-leasing conditions. This resulted in various withdrawn bids, because the private sector was uncertain about market profits. As an alternative, the district government reset the land-leasing condition into a shared lease among four local real estate companies. The developers, although they gained the development rights to the land, were required to merge as Xiaokang Real Estate Co., Ltd (XREC), following the decision of the district government. Such a decision revealed a strong state intervention in the bidding of land use rights. Furthermore, a special leadership team from the district government took charge of supervising the development process. Their supervision approaches included rewards and penalties for the developer, so as to ensure that the development of Luodong stayed in line with the xiaokang community scheme.

The mixed development provided the government with an opportunity to shift its financial burden of subsidising affordable housing to the private sector. XREC paid 203 million Yuan for land-leasing, housing and public goods provision, and upgrading suburban infrastructure, all of which were financed by the company's private funds and housing sales through market approaches. Even so, market profits from developing Luodong were much lower than XREC expected. This was because the district government controlled Luodong as affordable housing. 
Regulated services and disabled HOA. The mixed development was regulated to have an economic package of services. Although a professional management company was hired, homeowners were hardly capable of using market mechanisms for community maintenance. The local Housing and Urban Planning Bureau set the prices for community services so as to ensure that services were affordable to middle-income and low-income community members. The market provider had limited profit from managing the community, and thus reduced services to keeping things hygienic and collecting garbage. In Luodong, 70\% of residents were rural hukou holders. Although not pursuing a high-end suburban lifestyle in the community, they reported 'frequent dissatisfactions with community services' (Resident, interviewed on $07 / 01 / 2014$ ).

The district government supported the establishment of an HOA, considering it as an innovative method to save public expenditure on the supervision of community management. However, the community maintenance funds were controlled by the government, leaving minimal financial resources for the HOA. The HOA was incapable of carrying out neighbourhood improvement plans, but struggled with dissatisfaction regarding service provision. Therefore, this form of governance in mixed development was hardly a bottom-up mode of self-governance, neither was it an 'exit option' (Cséfalvay, 2011) for residents who were dissatisfied with the quality of urban governance.

\section{European Town: state-led gated residential development}

European Town offered a case of state-led residential development. Although developed similarly to a gated community, European Town was targeted at residents relocated due to policy requirements. Its development and governance were hardly attributed to private governance. European Town rather revealed the dominant role of the state in urban redevelopment.

State-dominated regeneration. The local government planned city centre redevelopment as an entrepreneurial strategy to regenerate urban space and to upgrade the service industry. Policy focuses were to redevelop deteriorated urban areas into high-class residential and commercial developments, aiming at speeding up local 
economic growth. At the end of the 1990s, Wenzhou municipal government launched a large-scale property-led redevelopment to reshape the old city. The site for European Town was not an urban village where housing and property ownerships were ambiguous. Land ownerships were clear, including 150 certificated individual houses and an established area of $35,000 \mathrm{~m}^{2}$ hosting traditional retailing business. The redevelopment plan claimed the existing residential area to be disordered with dilapidated and illegal houses. The redevelopment proposal was to develop a gated community with exotic landscapes, which would effectively contribute to a modern environment, and upgrade the taste (dangci) of the area.

The municipal government decided that the housing for existing property owners would be an on-site relocation. The redevelopment neither followed experiences in Shanghai, where the local government moved urban villagers to remote locations $(\mathrm{Wu}$ et al., 2013), nor was there an enormous compensation fee. The reason was that the state maintained ownership of the land. The land ownership enabled the municipal government to demolish illegal houses and to replace dilapidated houses with a gated community.

In the city centre regeneration process, local revenues were gained from leasing residential and commercial land, as well as taxing business and consumption. In the case of European Town, the municipal government planned the project to contain $25,000 \mathrm{~m}^{2}$ more commercial land than the standard for usual residential projects, emphasising commercial development. It adopted the concept of 'master-planned communities' to package the commercial area. As the name 'European Town' indicated, the project was designed with a coherent code of classic European landscape, such as Roman arches and Italian plazas, mimicking a recreational atmosphere in both commercial and residential areas. The use of gates in the residential area was to prevent the relocation from disturbing and being disturbed by the main commercial zone.

The planning of European Town was a decision of the municipal government. It reflected the municipal government's logic to financialise the city centre regeneration by using its total control over urban land and housing development. European Town succeeded in becoming a landmark for commerce, entertainment and residence in the 
city centre, leading to the growth of service businesses. More importantly, the regeneration caused land-leasing prices to soar, contributing huge local revenues.

State-owned enterprise as the developer. Apart from proposing a regeneration plan, the municipal government played a dominating role throughout the development process. European Town did not rely on market forces for development. The municipal government was in direct charge of relocation compensation. A special executive department, named the Jiangbin Road Redevelopment Office, was established to implement demolition and relocation. It further set up an affiliated company - European Town Construction and Management Co., Ltd (ETCMC) - to carry out project construction. The municipal government aimed to use two approaches for reducing financial burdens during the city centre regeneration process. First, it turned compensation for relocation into selling housing to the relocated. The gated community was planned to have a large average floor area. The redevelopment office offered existing property owners a discounted price to purchase housing in European Town, on the condition that compensation fees were used as deposits. In a sense, the relocation only guaranteed property owners a chance to buy at a relatively low price.

Second, the municipal government allocated the land use rights of European Town to ETCMC, providing special guidance for the development process. ETCMC was obliged to finance, construct, and manage European Town by itself like a private real estate company. Being an SOE, ETCMC had advantages in gaining financial resources such as mortgage loans. To meet the municipality's regeneration targets, ETCMC spent heavily to mimic European-style landscape and provided a variety of public goods, including community clubs, management offices and recreational facilities. Later, ETCMC used housing sales and the bonus of running commercial businesses in European Town as the main sources to make up for the financial deficiency.

Non-market approaches for governance. European Town also established an HOA and hired a professional company for management. However, community governance in the state-led development was fundamentally different from private governance. First, ETCMC retained a role in community governance after the 
completion of construction. It took responsibility for many sequels to the redevelopment, including administering the commercial area and handling residents' disputes over relocation in European Town, as well as carrying out further regeneration.

Second, ETCMC, as an SOE controlled by the municipal government, selected another SOE to provide property management services and charge residents monthly service fees. This selected property management company also belonged to the municipal government. Its main business was the management of the properties of large public facilities such as the municipal museum. In European Town, the HOA was not able to select its property management company according to its preference. The selection of property management was decided by the developer. As a result, the property management company collaborated with the developer and the local government behind it.

Third, the fee-paying scheme was ineffective in European Town. The relocated residents were reluctant to pay for property management, which used to be free in their previous properties. ETCMC made a compromise for the relocated to pay less than one-third of the market price for the same services. The fieldwork identified that a small proportion of urban villagers refused to pay the service fees, and considered themselves as 'being forced to consume' (Resident, interviewed on 08/01/2014). ETCMC had to subsidise the costs of community management by gaining additional financial resources, such as renting out property management offices.

Fourth, the establishment of an HOA was required by the municipal government according to new housing regulations. In fact, by the time of our fieldwork, the HOA in European Town had been dissolved owing to lack of participation. There was hardly any expectation for a new HOA discovered among property owners. Residents were involuntarily relocated to European Town. There was no self-governance to protect residents' rights against redevelopment policies in the early stage, nor did the HOA secure residents' benefits in the settlement neighbourhood. 


\section{Conclusion}

Research on gated communities has concentrated on the change of residential preferences and local governance towards private governance (Pow, 2011; Webster, 2002). In post-reform China, various gated neighbourhoods have developed, including neighbourhoods of commodity housing, affordable housing and resettlement housing. The scope of gatedness goes beyond the concept of 'gated communities' under private governance. Examining three gated neighbourhoods in Wenzhou, this paper reveals diverse types of gated communities developed during the ongoing suburbanisation and regeneration processes. The development of gated neighbourhoods is attributed to a state decision, specifically for capturing land values, for transferring responsibilities on affordable housing and suburban infrastructure to the market, and for achieving the strategic goal of city centre regeneration. These gated neighbourhoods hardly represent a way of private governance. In contrast, the state retains neighbourhood control and intervenes in market provision.

Our study shows that gated neighbourhoods are not automatically linked to private governance. Table 1 summarises the findings of the roles of the state in these gated neighbourhoods. More specifically, the study confirms the role of the state throughout the processes of planning, development and governance of gated communities. This is achieved by the state's control of land-leasing. Specifically, the de facto landowner - the local government - plans gated communities as a new approach for residential development, meanwhile shifting responsibility for service provision, including the basic functions of maintenance, education and entertainment for neighbourhoods, to the market. The local government uses gated communities to redevelop rural villages and shanty areas lacking modern infrastructure without increasing the local financial burdens of neighbourhood provision. In this way, local government developed land and infrastructure on the one hand and on the other hand promoted real estate and service industries while facilitating urban spatial and economic upgrading.

(Insert Table 1 here) 
Furthermore, gated neighbourhoods in China experience different roles of the state in their development. Three approaches, i.e. market-led, mixed state and market, and state-led, reveal different deployments of the local government regarding land, housing and neighbourhood control. The reconstruction of governance of gated community development goes beyond just facilitating housing marketisation and property management professionalisation. The municipal government constrains market profits in a mixed development to fulfil a political mission of affordable housing delivery. Through dominating relocation development, the local government removes barriers, i.e., separating relocated housing to avoid disturbing new commercial and financial centres, to the process of state-led regeneration. Thus, local government's power over revenue achievement and resources redistribution during the suburbanisation and regeneration processes is strengthened. This further supports the argument that the dynamics of gated communities may alter due to varied political, economic and social conditions, going beyond simply being vehicles of urban neoliberalism (Le Goix and Webster, 2008).

Earlier research on gated communities in the US regarded them as a form of private governance due to HOAs' self-governance (McKenzie, 1998). In particular, homeowners reached decisions on community governance and influenced local provisions. In Chinese gated communities, there has been a greater use of the market method. The government has allowed developers to use services and provisions to attract consumers. But this kind of environment is not able to evolve into a self-governed community due to government intervention. As observed in other, older neighbourhoods, housing privatisation did not lead to the retreat of the state but rather provided a condition for the state to enhance its role in neighbourhood governance (Wu, 2018a). In these new gated developments, developers must negotiate land from the local government, in return taking over the government's task of property and infrastructure development as well as their maintenance. Market forces are used to manage residents' services too. However, the HOA lacks the power and financial resources to improve neighbourhood management. Residents in resettled housing did not choose the gated community. Developer and service provider were chosen by the local government, different from residents' wishes. In Chinese gated neighbourhoods, the state plays important roles in initiating development, regulating property 
management and maintaining neighbourhood control. Here the form of gated neighbourhoods together with associated market instruments has been deployed by the state to deliver its governance purposes (Wu, 2018b). The development of gated neighbourhoods in China reveals the persistent but variegated roles of the state, just as American gated communities represent the rise of private governance.

Acknowledgement: We are very grateful to the editorial team and anonymous referees for their helpful comments and suggestions. This work has been supported by the UK Economic and Social Research Council (ESRC) projects [ES/N015185/1, ES/P003435/1]. We also thank the funding support from Shanghai Jiao Tong University "the Fundamental Research Funds for the Central Universities" 17JCYA06.

\section{References}

Atkinson, R., Blandy, S., Flint, J., \& Lister, D. (2005). Gated cities of today?: Barricaded residential development in England. Town Planning Review, 76(4), $401-422$.

Blakely, E. J. \& Snyder, M. G. (1997). Fortress America: gated communities in the United States. Washington, DC: Brookings Institution Press.

Bray, D. (2005). Social space and governance in urban China: The danwei system from origins to reform. Stanford University Press.

Breitung, W. (2012). Enclave urbanism in China: Attitudes towards gated communities in Guangzhou. Urban Geography, 33(2), 278-294.

Buchanan, J. M. (1965). An economic theory of clubs. Economica, NS, 32(125), 1-14.

Charmes, E. (2009). On the residential 'clubbisation' of French periurban municipalities. Urban Studies, 46(1), 189-212.

Coy, M., \& Pöhler, M. (2002). Gated communities in Latin American megacities: case studies in Brazil and Argentina. Environment and Planning B: Planning and Design, 29(3), 355-370. 
Cséfalvay, Z. (2011). Gated communities for security or prestige? A public choice approach and the case of Budapest. International Journal of Urban and Regional Research, 35(4), 735-752.

Douglass, M., Wissink, B., \& van Kempen, R. (2012). Enclave urbanism in China: consequences and interpretations. Urban Geography, 33(2), 167-182.

Dowling, R., Atkinson, R., \& McGuirk, P. (2010). Privatism, privatisation and social distinction in master-planned residential estates. Urban Policy and Research, 28(4), 391-410.

Fauveaud, G. (2016) Residential enclosure, power and relationality: Rethinking sociopolitical relations in southeast Asian cities. International Journal of Urban and Regional Research, 40(4), 849-865.

Foldvary, F. (1994). Public Goods and Private Communities: The Market Provision of Social Services. London: Edward Elgar.

Glasze, G., Webster, C., \& Frantz, K. (2006). Private Cities: Global and Local Perspectives. London: Routledge.

Gordon, M. (2004). Planned Developments in California: Private Communities and Public Life. San Francisco CA: Public Policy Institute of California.

He, S. (2013). Evolving enclave urbanism in China and its socio-spatial implications: the case of Guangzhou. Social \& Cultural Geography, 14(3), 243-275.

He, S. (2015). Homeowner associations and neighborhood governance in Guangzhou, China. Eurasian Geography and Economics, 56(3), 260-284.

Hendrikx, M., \& Wissink, B. (2017). Welcome to the club! An exploratory study of service accessibility in commodity housing estates in Guangzhou, China. Social \& Cultural Geography, 18(3), 371-394.

Hirschman, A. O. (1970). Exit, Voice, and Loyalty: Responses to Decline in Firms, Organizations, and States. Cambridge: Harvard University Press. 
Hogan, T., Bunnell, T., Pow, C. P., Permanasari, E., \& Morshidi, S. (2012). Asian urbanisms and the privatization of cities. Cities, 29(1), 59-63.

Huang, Y. (2006). Collectivism, political control, and gating in Chinese cities. Urban Geography, 27(6), 507-525.

Imrie, R., \& Raco, M. (1999). How new is the new local governance? Lessons from the United Kingdom. Transactions of the Institute of British Geographers, 24(1), $45-63$.

Kirby, A. (2008). The production of private space and its implications for urban social relations. Political Geography, 27(1), 74-95.

Labbé, D., \& Boudreau, J. A. (2015). Local integration experiments in the new urban areas of Hanoi. South East Asia Research, 23(2), 245-262.

Le Goix, R., \& Webster, C. J. (2008). Gated communities. Geography Compass, 2(4), $1189-1214$.

Low, S. M. (2003). Behind the Gates: Life, Security, and the Pursuit of Happiness in Fortress America. New York: Routledge.

McKenzie, E. (1998). Homeowner associations and California politics: An exploratory analysis. Urban Affairs Review, 34(1), 52-75.

Morange, M., Folio, F., Peyroux, E., \& Vivet, J. (2012). The spread of a transnational model: 'gated communities' in three Southern African cities (Cape Town, Maputo and Windhoek). International Journal of Urban and Regional Research, 36(5), 890-914.

Miao, P. (2003). Deserted streets in a jammed town: The gated community in Chinese cities and its solution. Journal of Urban Design, 8(1), 45-66.

Ortega, A. (2012). Desakota and beyond: Neoliberal production of suburban space in Manila's fringe. Urban Geography, 33(8), 1118-1143.

Pow, C. P. (2009). Gated Communities in China: Class, Privilege and the Moral 
Politics of the Good Life. London: Routledge.

Pow, C. P. (2011). Living it up: super-rich enclave and transnational elite urbanism in Singapore. Geoforum, 42(3), 382-393.

Roitman, S., Webster, C., \& Landman, K. (2010). Methodological frameworks and interdisciplinary research on gated communities. International Planning Studies, 15(1), 3-23.

Rosen, G., \& Grant, J. (2011). Reproducing difference: Gated communities in Canada and Israel. International Journal of Urban and Regional Research, 35(4), 778-793.

Rosen, G., \& Razin, E. (2009). The rise of gated communities in Israel: Reflections on changing urban governance in a neo-liberal era. Urban Studies, 46(8), $1702-1722$.

Shen, J., \& Wu, F. (2017). The suburb as a space of capital accumulation: the development of new towns in Shanghai, China. Antipode, 49(3), 761-780.

Tedong, P. A., Grant, J. L., Aziz, W. A., \& Azriyati, W. N. (2015). Governing enclosure: the role of governance in producing gated communities and guarded neighborhoods in Malaysia. International Journal of Urban and Regional Research, 39(1), 112-128.

Walks, R. A. (2008) Urban form, everyday life, and ideology: support for privatization in three Toronto neighbourhoods. Environment and Planning A, 40(2), 258282.

Wang, Y. P., \& Murie, A. (2000). Social and spatial implications of housing reform in China. International Journal of Urban and Regional Research, 24(2), 397-417.

Webster, C. (2002) Property rights and the public realm: gates, green belts, and Gemeinschaft. Environment and Planning B, 29(3), 397-412.

Webster, C., Wu, F., \& Zhao, Y. (2006). China's modern gated cities. In G. Glasze, C. Webster, and K. Frantz (eds.) Private Cities: Global and Local Perspectives. 
London: Routledge, pp. 139-150.

Wenzhou Statistical Bureau. (2010). Wenzhou Statistical Yearbook 2010. Wenzhou: Wenzhou Statistical Bureau.

Wissink, B., Van Kempen, R., Fang, Y., \& Li, S. M. (2012). Introduction-Living in Chinese enclave cities. Urban Geography, 33(2), 161-166.

Wu, F. (2005). Rediscovering the 'gate' under market transition: from work-unit compounds to commodity housing enclaves. Housing Studies, 20(2), 235-254.

Wu, F. (2010). Gated and packaged suburbia: Packaging and branding Chinese suburban residential development. Cities, 27(5), 385-396.

$\mathrm{Wu}, \mathrm{F}$. (2016). State dominance in urban redevelopment: Beyond gentrification in urban China. Urban Affairs Review, 52(5), 631-658.

Wu, F. (2018a). Housing privatization and the return of the state: changing governance in China. Urban Geography, 39(8), 1177-1194.

Wu, F. (2018b). Planning centrality, market instruments: governing Chinese urban transformation under state entrepreneurialism. Urban Studies, 55(7), 13831399.

Wu, F., Zhang, F., \& Webster, C. (2013). Informality and the development and demolition of urban villages in the Chinese peri-urban area. Urban Studies, 50(10), 1919-1934.

$\mathrm{Xu}, \mathrm{F}$. (2008). Gated communities and migrant enclaves: the conundrum for building 'harmonious community/shequ'. Journal of Contemporary China, 17(57), $633-651$.

Zhang, L. (2010). In Search of Paradise: Middle-class Living in A Chinese Metropolis. Ithaca, NY: Cornell University Press.

Zhou, Y. \& Logan, J. R. (2008). Growth on the edge: the new Chinese metropolis, in J. R. Logan (ed.) Urban China in Transition. Oxford: Blackwell Publishing, pp. 
140-160. 
Table 1 The role of the state in variegated gated communities in Wenzhou, China

\begin{tabular}{|c|c|c|c|}
\hline \multirow{2}{*}{$\begin{array}{l}\text { Variegated types of } \\
\text { gated communities }\end{array}$} & \multicolumn{3}{|c|}{ The role of the state } \\
\hline & $\begin{array}{l}\text { Development } \\
\text { objectives }\end{array}$ & $\begin{array}{l}\text { Property } \\
\text { management }\end{array}$ & $\begin{array}{l}\text { Neighbourhood } \\
\text { governance }\end{array}$ \\
\hline Commodity housing & $\begin{array}{l}\text { Overcoming } \\
\text { infrastructure } \\
\text { constraints using } \\
\text { market forces }\end{array}$ & $\begin{array}{l}\text { Using professional } \\
\text { property } \\
\text { management } \\
\text { companies to } \\
\text { reduce } \\
\text { expenditures on } \\
\text { neighbourhood } \\
\text { service }\end{array}$ & $\begin{array}{l}\text { Limiting HOA by } \\
\text { neighbourhood } \\
\text { agencies } \\
\text { (Residents' } \\
\text { Committee and } \\
\text { Street Office) }\end{array}$ \\
\hline Affordable housing & $\begin{array}{l}\text { Providing } \\
\text { subsidised } \\
\text { housing }\end{array}$ & $\begin{array}{l}\text { Indirect } \\
\text { intervening and } \\
\text { regulating } \\
\text { standards and } \\
\text { profits }\end{array}$ & $\begin{array}{l}\text { Disabled } \\
\text { homeowners' } \\
\text { association }\end{array}$ \\
\hline Resettlement housing & $\begin{array}{l}\text { Facilitating inner } \\
\text { urban regeneration }\end{array}$ & $\begin{array}{l}\text { Specially } \\
\text { appointing } \\
\text { state-owned } \\
\text { enterprises }\end{array}$ & $\begin{array}{l}\text { Residential } \\
\text { relocation through } \\
\text { the government }\end{array}$ \\
\hline
\end{tabular}

Figure 1 Locations of three gated communities in Wenzhou 